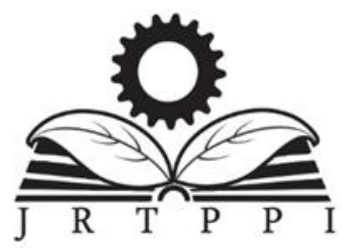

Vol. 12 No. 2 (2021) 34-44

Jurnal Riset

Teknologi Pencegahan Pencemaran Industri

Kementerian

Perindustrian

REPUBLIK INDONESIA

Journal homepage : http://www.jrtppi.id

\title{
Biogas Production from Sugarcane Vinasse: A Review
}

\author{
Rustiana Yuliasni ${ }^{1^{*}}$, Rieke Yuliastuti ${ }^{2}$, Nanik Indah Setianingsih ${ }^{1}$ \\ ${ }^{1}$ Balai Besar Teknologi Pencegahan Pencemaran Industri, Jalan Ki Mangunsarkoro No. 6 Semarang \\ ${ }^{2}$ Balai Riset dan Standardisasi Industri Surabaya
}

A R T IC L E I N F O

Article history:

Received 07 July 2021

Received in revised form 23 September 2021

Accepted 23 September 2021

Available online 10 December 2021

Keywords :

Agro-Industrial wastewater

Biogas

Methane

Sugarcane vinasse

Wastewater technology

\begin{abstract}
A B S T RACT
Biogas is a renewable energy sources that could replace the role of fossil fuel. Biogas could be produced from biomass or agro-industrial wastewater. Sugarcane vinasse has potential of biogas production due to its high BOD concentration (10-65 g BOD/L). However, the biogas production from sugarcane vinasse has several drawbacks that hinders the maximum biogas yield, such as: acidic $\mathrm{pH}(\mathrm{pH} 3.5-5.0)$, high temperature $\left(80-90^{\circ} \mathrm{C}\right)$ and high concentration of sulfuric acid ( $>150 \mathrm{mg} / \mathrm{L}$ ). Theoretically, the methane potential per gram COD is $0.35 \mathrm{~L} / \mathrm{gr}$ COD, containing of $60 \%$ methane. However, up to date, the maximum biogas production from vinasse was less then its theoretical value. To get the full potential of biogas production from vinasse wastewater as well as to reduce the capital cost for full scale application, combination of suitable pre-treatment, selected microorganisms and bioreactor designconfiguration are the most important parameters to be considered. This paper aims to explore the potential of sugarcane vinasse to produce biogas, by elaborating the aforementioned key parameters. In this review the basic characteristic and the potency of sugarcane vinasse wastewater will be elaborated. Furthermore, the effect of key parameters such as $\mathrm{pH}$, temperature, and organic load to biogas production will also be discussed. The biogas technology will also be explored. Lastly, conclusion will be determined.
\end{abstract}

\section{INTRODUCTION}

Indonesia is amongst the biggest ethanol producer in the world, alongside Brazil, India, and China (OECD/FAO, 2019). At recent days, the ethanol production demand increases due to the extreme need for disinfectant. In Indonesia, sugar cane and molasses are the major feedstocks in the ethanol agro-industry. There are big, as well as small-medium scale of agro-industries that produce ethanol from molasses. For instance, one big ethanol industry in Central Java-Indonesia, PT Indo Acidatama has maximum production capacity of 80 million liter ethanol per year (Harihastuti \& Marlena, 2018). As for small scale industries, there are about 130 industries in Polokarto, Sukoharjo, Central Java that produce alcohol total amount of 13,000 L/per day (around 80-100 L alcohol/industry/day) (Harihastuti et al., 2020; Harihastuti \& Marlena, 2018)

The environmental problem related to the developing ethanol agro-industry is vinasse wastewater, as a by-product of ethanol production. For every liter of ethanol production, approximately $10-15$ liters vinasse is generated (Bernal et al., 2017; Naspolini et al., 2017). Figure 1 depicts a flowchart of ethanol production from sugarcanes and pollution prevention strategies. Figure 1 shows that vinasse is a wastewater that generated from stripping and distillation process. Vinasse wastewater has low $\mathrm{pH}$, high COD, dark-colored, high concentration of

\footnotetext{
*Correspondence author.

E-mail : rustianay@yahoo.com (Rustiana Yuliasni)
} 
sulfur and bad odor (Cristiano E Rodrigues Reis, Hu, \& $\mathrm{Hu}, 2017)$. The easiest way to utilize vinasse wastewater is using it as fertilizer/fertirrigation. Technologies, such as anaerobic digestion $(\mathrm{AD})$, advanced oxidation process (AOP), biological based treatment using algae and fungi are also commonly used as treatment strategy. The aforementioned technologies could treat vinasse wastewater so that the effluent can fulfil the water reuse standard. The effluent could be reused in the fermentative process. Bagasse, the solid waste that comes from juice extraction process, is used as feed to the boiler to produce steam and heat.

Anaerobic digestion $(\mathrm{AD})$ is proven to be the most beneficial treatment for vinasse wastewater mitigation management. $\mathrm{AD}$ produces bioenergy (methane) that can be utilized as fuel replacing fossil fuel in the distillation process, as well as generate bio-fertilizer. Theoretically, the methane potential per gram COD is $0.35 \mathrm{~L} /$ gr COD, with $60 \%$ methane content. From $1 \mathrm{~m}^{3}$ vinasse, about 115-312 $\mathrm{m}^{3}$ of biogas can be produced, from which $169 \mathrm{~kW}$ of energy can be generated (Meyer, Rein, Turner, Administrative, \& Mcgregor, 2011). The energy efficiency of the biogas produced from the vinasse in reciprocating combustion engines is $29 \%$, while it is $32 \%$ in the gas turbines and microturbines (Parsaee, Kiani, Kiani, \& Karimi, 2019). The total energy in vinasse is about $18 \%$ of the energy produced by bioethanol produced in the plant (Meyer et al., 2011). Unfortunately, methane production from vinasse cannot reach to its maximum potential due to many factors, such as: high level of inhibitors (Jesus, Bastos, \& Altenhofen, 2019), low $\mathrm{C} / \mathrm{N}$ ratio than the optimum $\mathrm{C} / \mathrm{N}$ yield in biogas system (Janke, Leite, Nikolausz, Schmidt, \& Liebetrau, 2015; Kayhanian \& Rich, 1995), the needed HRT to achieve full organic degradation (Janke et al., 2015), low pH (Harihastuti et al., 2021; Cristiano E Rodrigues Reis et al., 2017), type of microorganisms (Oliveira et al., 2020), etc. Hence, for full scale application, addressing those factors is important thing to do.

Literatures about biogas potential from vinasse wastewater are still limited. This paper will generally review the potential of biogas production from vinasse wastewater. Specifically, the characteristic of vinasse along with its environmental effect and treatment technology will be elaborated. In addition, this paper also addresses the various aspects that have to be considered to enhance biogas generation of vinasse. Furthermore, its full-scale applications are also discussed. Lastly, the conclusion is determined.

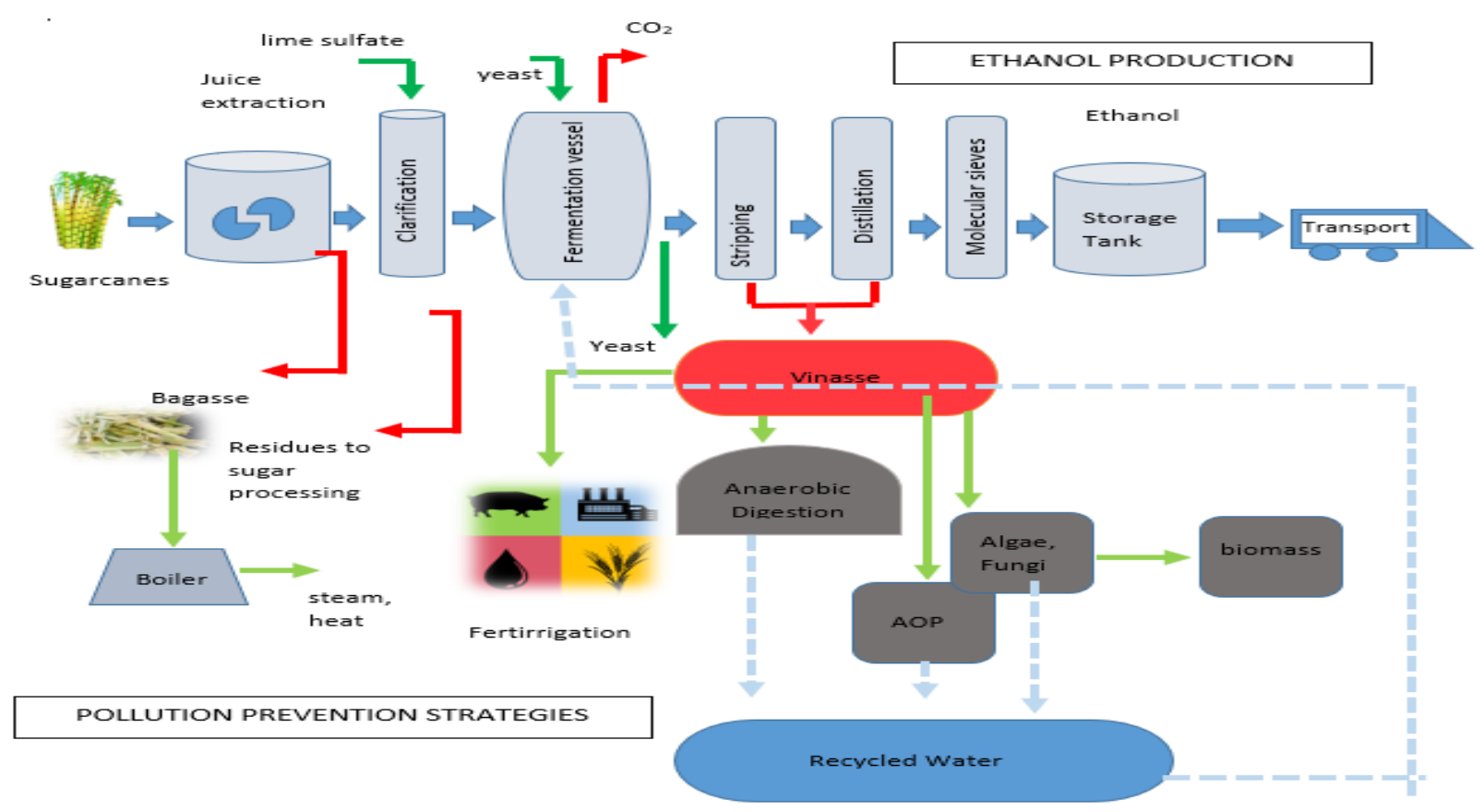

Figure 1. Flowchart of ethanol production and pollution prevention strategies 
Table 1. Properties of sugarcanes vinasse wastewater

\begin{tabular}{|c|c|c|c|}
\hline Parameter & Unit & Concentration range & Ref. \\
\hline $\mathrm{pH}$ & - & $3.0-5.0$ & $\begin{array}{l}\text { (Harihastuti et al., 2021; Iqbal Syaichurrozi, } \\
\text { 2016) }\end{array}$ \\
\hline Temperature & ${ }^{\circ} \mathrm{C}$ & $40-50$ & (Harihastuti \& Marlena, 2018) \\
\hline Biochemical Oxygen Demand (BOD) & $\mathrm{mg} / \mathrm{L}$ & $23,182-109,038$ & $\begin{array}{l}\text { (Harihastuti \& Marlena, 2018; Soares et al., } \\
\text { 2019; Iqbal Syaichurrozi, 2016) }\end{array}$ \\
\hline Chemical Oxygen Demand (COD) & $\mathrm{mg} / \mathrm{L}$ & $32,400-353,797$ & $\begin{array}{l}\text { (Harihastuti \& Marlena, 2018; Janke et al., } \\
\text { 2015) }\end{array}$ \\
\hline Total Organic Carbon (TOC) & $\mathrm{mg} / \mathrm{L}$ & 30,750 & (Iqbal Syaichurrozi, 2016) \\
\hline $\mathrm{C} / \mathrm{N}$ ratio & - & $11-15 / 1$ & (Janke et al., 2016) \\
\hline Total Suspended Solid (TSS) & $\mathrm{mg} / \mathrm{L}$ & 7,200 & (Harihastuti \& Marlena, 2018) \\
\hline Total Solid (TS) & $\mathrm{mg} / \mathrm{L}$ & $27,000-81,500$ & (Parsaee, Kiani, et al., 2019) \\
\hline Volatile Suspended solid (VSS) & $\mathrm{mg} / \mathrm{L}$ & $1,620-15,860$ & (Parsaee, Kiani, et al., 2019) \\
\hline Total Nitrogen (TN) & $\mathrm{mg} / \mathrm{L}$ & 17,920 & (Janke et al., 2016) \\
\hline Total Phosphate (TP) & $\mathrm{mg} / \mathrm{L}$ & $1-102$ & (Iqbal Syaichurrozi, 2016) \\
\hline Sulfide $\left(\mathrm{H}_{2} \mathrm{~S}\right)$ & $\mathrm{mg} / \mathrm{L}$ & $6.55-39.7$ & (Harihastuti et al., 2020, 2021) \\
\hline Volatile Fatty Acid (VFA) & $\mathrm{mg} / \mathrm{L}$ & 1,310 & (Lebrero \& Zaiat, 2017) \\
\hline Bicarbonate Alkalinity & $\mathrm{mg} \mathrm{CaCO}_{3} / \mathrm{L}$ & 295 & (Parsaee, Kiani, et al., 2019) \\
\hline Phenols & $\mathrm{mg} / \mathrm{L}$ & $0.45-0.469$ & (Parsaee, Kiani, et al., 2019) \\
\hline Iron $(\mathrm{Fe})$ & $\mathrm{mg} / \mathrm{L}$ & $200-488$ & (Janke et al., 2015) \\
\hline Manganese (Mn) & $\mathrm{mg} / \mathrm{L}$ & $55.4-194$ & (Janke et al., 2016, 2015) \\
\hline Nickel (Ni) & $\mathrm{mg} / \mathrm{L}$ & $0.47-2.30$ & (Janke et al., 2016, 2015) \\
\hline Copper $(\mathrm{Cu})$ & $\mathrm{mg} / \mathrm{L}$ & $3.62-7.96$ & (Janke et al., 2016, 2015) \\
\hline Zinc $(\mathrm{Zn})$ & $\mathrm{mg} / \mathrm{L}$ & $29.4-36.8$ & (Janke et al., 2016, 2015) \\
\hline Cobalt (Co) & $\mathrm{mg} / \mathrm{L}$ & $0.53-0.62$ & (Janke et al., 2016, 2015) \\
\hline Molybdenum (Mo) & $\mathrm{mg} / \mathrm{L}$ & $0.48-0.84$ & (Janke et al., 2016, 2015) \\
\hline Selenium (Se) & $\mathrm{mg} / \mathrm{L}$ & 0.08 & (Janke et al., 2015) \\
\hline
\end{tabular}

\section{CHARACTERISTICS OF SUGARCANES VINASSE WASTEWATER}

The characteristics of vinasse wastewater depends on the raw materials (i.e. the variety of sugarcanes and the quality of molasses) and the process technology (i.e. the operating condition of the ethanol production, type of fermentation and distillation process, the quantity of the chemicals used, etc (Soares, Zaiat, Augusto, \& Tadeu, 2019; 
Wilkie, Riedesel, \& Owens, 2000). Sugarcanes wastewater, that comes from ethanol distillation process, is considered as recalcitrant. It has temperature of $65-107^{\circ} \mathrm{C}$ and a $\mathrm{pH}$ of 3-5 (Albuquerque, Ratusznei, \& Rodrigues, 2019; Harihastuti \& Marlena, 2018). Sugarcane vinasse contains of $93-97 \%$ water (Pazuch et al., 2017), 5\% organic matter and $2 \%$ inorganic insoluble solid (Parsaee, Kiani, et al., 2019). It easily dissolves in water and has dark brown color.

The dark brown pigment is derived from phenolic compounds (tannin and humic acids), melanoidins and caramels that makes vinasse is toxic to microorganisms. The characteristic of sugarcanes vinasse can be seen in Table 1 .

\section{ENVIRONMENTAL IMPACT}

Sugarcane vinasse is considered very polluting because of high organic load that causes proliferation of microorganisms that reduces the dissolved oxygen (DO) in the water body that makes water unconsumable. Sugarcane vinasse also has low $\mathrm{pH}$ and corrosive. Its degree of pollution can be 100 times more dangerous than domestic waste (Marafon, Salomon, \& Lucena, 2020). The lowest maintenance utilization of vinasse wastewater is using it as fertirrigation, as it requires low initial investment, low maintenance cost and simple technology (Marafon, Salomon, \& Lucena, 2020). However, the bad effect of the excessive use of vinasse as fertirrigation are ground water contamination, soil salinization, metal leach and greenhouse gas emission (GHG) such as nitrous oxide, which is about 300 times more polluting than carbon dioxide $\left(\mathrm{CO}_{2}\right)$ (Marafon, Salomon, Amorim, \& Peiter, 2020). Furthermore, over a long period of time, frequent discharges to the soil, rivers or lake could be harmful to the biota. However, vinasse wastewater fertirrigation could be very beneficial to improve soil fertility, with optimum dosage supplement that should not be exceed the soil's ion retention capacity (Tadeu, Loureiro, \& Zaiat, 2018). Thus, the optimum dosage should be determined based on soil properties.

\section{SUGARCANES VINASSE TREATMENT METHODS}

Due to its high organic content, the treatment of vinasse wastewater should not be only rely on single method. The combination of several technology should be applied for the effluent in order to fulfill stream standard regulation. Biological treatment is till most common preference. The combination of biological anaerobic and aerobic treatment is the best solution to treat vinasse wastewater (Harihastuti et al., 2021). To improve the effluent's quality for re-use, another add-on advance technology such as ozonation catalytic might be used. Beside proven technologies, there are also several advance methods that also able to treat sugarcane vinasse wastewater effectively. Table 2 shows sugarcanes vinasse wastewater treatment technology.

\section{ANAEROBIC DIGESTION OF SUGARCANE VINASSE}

Sugarcane vinasse anaerobic digestion follows the already known mechanism of anaerobic process that involves anaerobic bacteria. Anaerobic process is consisting of four phases that works simultaneously, namely : hydrolysis, acidogenesis, acetogenesis and methanogenesis phase. Figure 2 shows anaerobic digestion phase of sugarcane vinasse wastewater. The process begins with the decomposition of complex organic compound into smaller molecules such as polysaccharide, lipid and protein. The second stage is called hydrolysis, where polysaccharide would be hydrolyzed into glucose, lipid was hydrolyzed into fatty acid, and protein into amino acid. Third phase, acidogenesis, is where glucose degrades into different types of VFA's (acetic, butyric, propionic, etc), ethanol and $\mathrm{CO}_{2}$. The forth phase is called acetogenesis, where all VFA's change into acetic acid and $\mathrm{CO}_{2}$. The last phase is methanogenic, where methane, $\mathrm{CO}_{2}$ and water are the only products left. The type microorganism involved in the anaerobic process was also a mixture of different types of bacteria that follows syntrophic reaction. The dominant microbial community is shifting at each phase, as shown in figure 3 (Zimmerman, 2016). 
Table 2 Reviews several methods that are able to treat sugarcanes vinasse wastewater. Better formatting of the table below

\begin{tabular}{|c|c|c|c|c|c|}
\hline Treatment methods & COD in $(g / L)$ & $\%$ COD removal (\%) & Design Parameter & Type of Application & Ref. \\
\hline 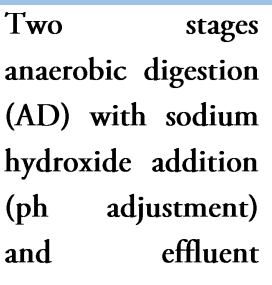 & $\begin{array}{l}\text { - Acidogenesis } \\
\text { stage : } 84.2 \mathrm{~kg}^{-} \\
\text {COD m} \mathrm{m}^{-3} \mathrm{~d}^{-1} \\
\text { - methanogenesis } \\
\text { stage }=25 \mathrm{~kg}^{-} \\
\text {COD m}{ }^{-3} \text { day }^{-1}\end{array}$ & $\begin{array}{l}\text { - Acidogenesis stage: } \\
21.2 \% \\
\text { - methanogenesis stage = } \\
73.9 \%\end{array}$ & $\begin{array}{l}\text { HRT } 232 \text { days (harvested } \\
\text { time) }\end{array}$ & $\begin{array}{l}\text { - Acidogenesis stage : } \\
\text { packed bed reactor lab } \\
\text { scale } \\
\text { - Methanogenesis } \\
\text { stage: structured-bed } \\
\text { reactors }\end{array}$ & $\begin{array}{l}\text { (Tadeu, } \\
\text { Messias, } \\
\text { Júnior, } \\
\text { Loureiro, \& } \\
\text { Zaiat, 2017) }\end{array}$ \\
\hline recirculation & & & & & \\
\hline $\begin{array}{l}\text { Two-stage } \\
\text { Anaerobic } \\
\text { Membrane } \\
\text { Bioreactor }\end{array}$ & 16.706 & 97 & $\begin{array}{l}\text { HRT } 3.1-5.3 \text { days. } \\
\text { With two separated } \\
\text { acidogenic and } \\
\text { methanogenic tank }\end{array}$ & $\begin{array}{l}\text { Membrane bioreactor } \\
(\mathrm{MBR}) \text { Lab scale }\end{array}$ & $\begin{array}{l}\text { (Santos, Ricci, } \\
\text { Neta, } \& \\
\text { Amaral, 2017) }\end{array}$ \\
\hline $\begin{array}{l}\text { Single stage } \\
\text { Thermophilic } \\
\text { UASB }\end{array}$ & $35.2 \pm 2.6$ & 71.7 & $\mathrm{HRT}=34-56 \mathrm{hrs}$ & UASB reactor, Lab scale & $\begin{array}{l}\text { (Ferraz, } \\
\text { Koyama, } \\
\text { Araújo, \& } \\
\text { Zaiat, 2016) }\end{array}$ \\
\hline $\begin{array}{l}\text { Two-stage } \\
\text { Thermophilic } \\
\text { UASB }\end{array}$ & $24.0 \pm 1.8$ & 90.3 & $\mathrm{HRT}=32-39 \mathrm{hrs}$ & UASB, Lab scale & $\begin{array}{l}\text { (Ferraz et al., } \\
2016)\end{array}$ \\
\hline $\begin{array}{l}\text { Combination } \\
\text { coagulation } \\
\text { flocculation and } \\
\text { fenton oxidation }\end{array}$ & 6.836 & 69.2 & $\begin{array}{l}\text { 1) } \mathrm{pH} \text { adjustment with } \\
\mathrm{NaOH} \text { and } \mathrm{H}_{2} \mathrm{SO} 4 \\
\text { 2) Coagulant } \mathrm{FeCl}_{3} \text {, } \\
\text { stirring } 150 \mathrm{rpm} \text { for } 3 \\
\text { mins } \\
\text { 3) Flocculation }=15 \text { mins, } \\
\text { 4) Settling }=20 \mathrm{hrs} \\
\text { 5) Fenton } \mathrm{FeCl}_{3}+\mathrm{H}_{2} \mathrm{O}_{2} \text {, } \\
\text { HRT } 3 \mathrm{hrs}\end{array}$ & Lab scale & $\begin{array}{l}\text { (Guerreiro et } \\
\text { al., 2016) }\end{array}$ \\
\hline $\begin{array}{l}\text { Two stage Up flow } \\
\text { Anaerobic Filter, } \\
\text { with pH adjustment } \\
\text { and effluent } \\
\text { recirculation }\end{array}$ & $61-104$ & 71 & $\begin{array}{l}\text { Addition of } \mathrm{CaCO}_{3} \text { to } \mathrm{pH} \\
6, \quad 25 \% \quad \text { effluent } \\
\text { recirculate, }\end{array}$ & Two stages UAF, Full scale & $\begin{array}{l}\text { (Harihastuti et } \\
\text { al., 2021) }\end{array}$ \\
\hline $\begin{array}{l}\text { Anaerobic digestion } \\
\text { using UASB, with } \\
\text { Ozonation (AOP) } \\
\text { post treatment }\end{array}$ & 120 & $\begin{array}{l}\text { AD removes } 95 \% \text { to the } \\
\text { level COD of } 4.5 \mathrm{~g} / \mathrm{L} \text { (as } \\
\text { bio recalcitrant color). } \\
\text { AOP post treatment } \\
\text { removes } 80 \% \text { of the } \\
\text { color. }\end{array}$ & $\begin{array}{l}\text { Sludge granules from } \\
\text { settled UASB reactor, } \\
\text { VFA/Alk = } 0.4, \mathrm{pH} 7.5 \\
\text { Optimum Ozone dosage } \\
\text { of } 90 \mathrm{mg} / \mathrm{L} / \mathrm{min}\end{array}$ & UASB, Lab scale & $\begin{array}{l}\text { (Otieno \& } \\
\text { Apollo, 2020) }\end{array}$ \\
\hline $\begin{array}{l}\text { Ozone, anaerobic, } \\
\text { aerobic }\end{array}$ & 39.4 & $95 \%$ & $\begin{array}{l}120 \text { mins ozonation } \\
\text { followed with aeration } \\
\text { and peroxide removal } \\
\text { with using a } \mathrm{Na}_{2} \mathrm{CO}_{3} \\
\text { dosage at } 20 \mathrm{~g} \mathrm{~L}-1 \\
\text { following heating at } 90^{\circ} \mathrm{C} \\
\text { and magnetic stirring for } \\
14 \mathrm{~h} \text {. Aerobic treatment } \\
\text { was using } M . \\
\text { circinelloides }\end{array}$ & Lab scale & $\begin{array}{l}\text { (Cristiano E R } \\
\text { Reis, Bento, } \\
\text { Alves, } \\
\text { Carvalho, \& } \\
\text { Castro, 2019) }\end{array}$ \\
\hline
\end{tabular}




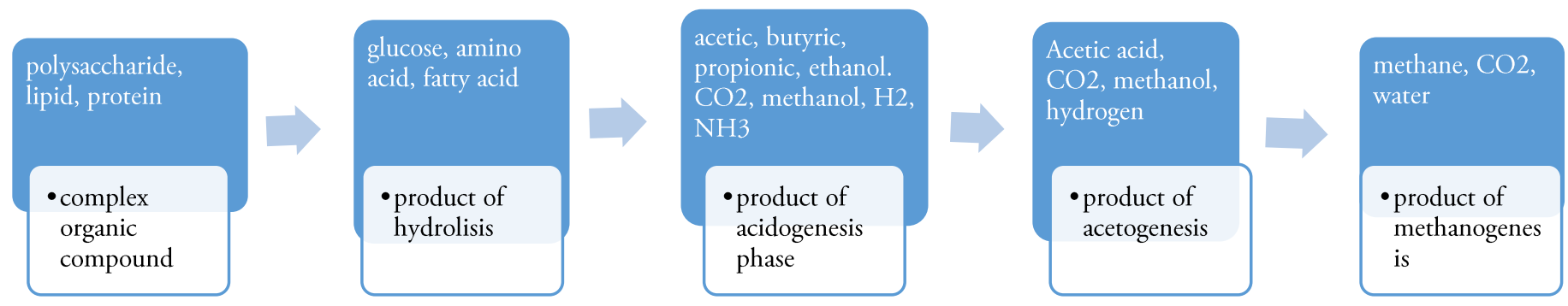

Figure 2. Anaerobic degradation phase of vinasse wastewater
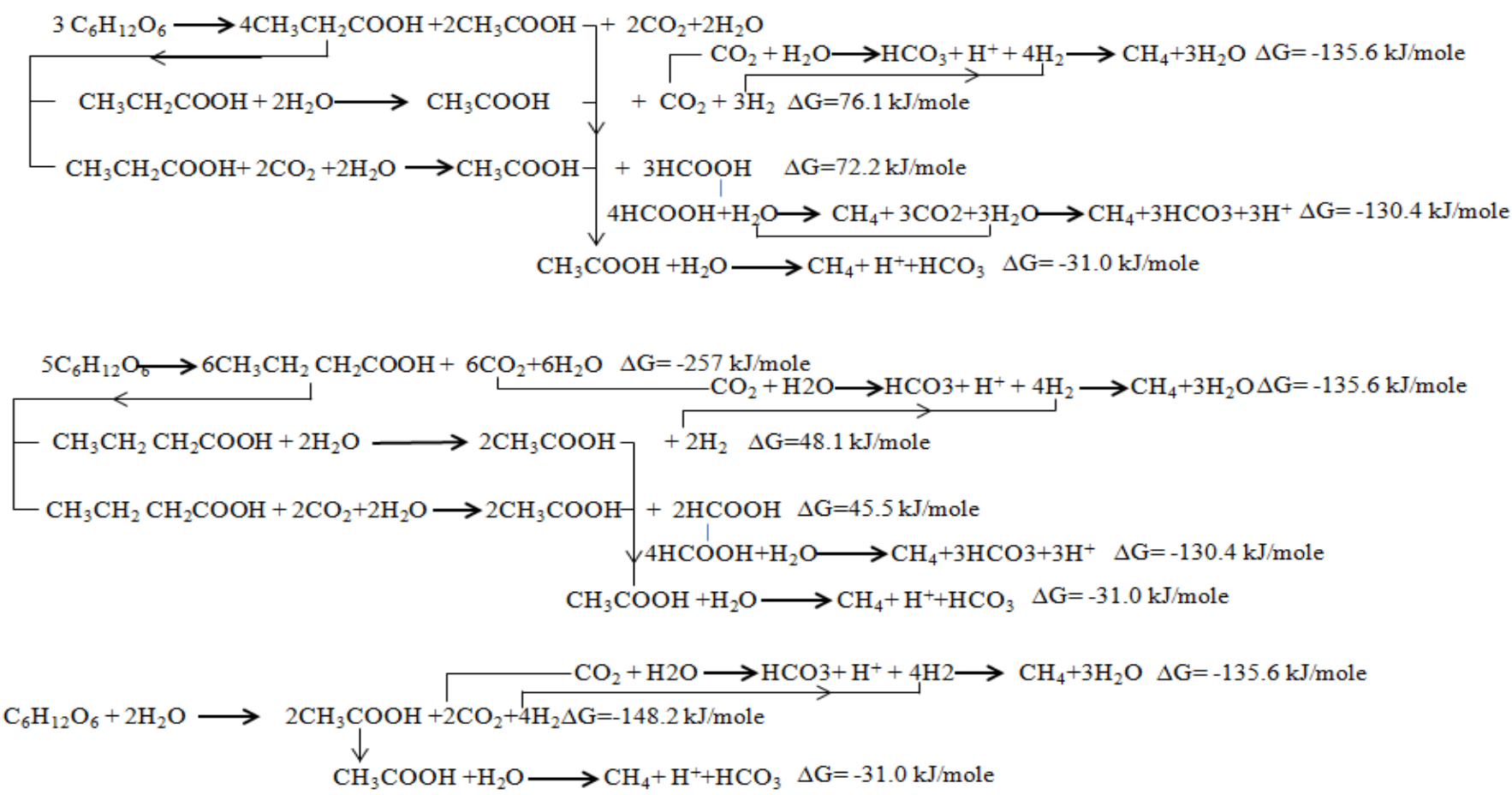

Figure 3. Biological reaction in anaerobic digestion, as referred from Al-mashhadani et.al (Zimmerman, 2016)

\section{VINASSE BIOGAS GENERATION}

A full-scale application for sugarcane vinasse treatment could be costly due to its high investment of infrastructure. To reduce the cost, utilization of biogas generated from sugarcane vinasse, as alternative energy, could be the better option. Sugarcane vinasse has high methane potential. Approximately, for every $1 \mathrm{~m}^{3}$ vinasse, $10-26.4 \mathrm{~m}^{3}$ of biogas could be produced, and equal to1.5$10 \mathrm{~kW}$ energy that could power engine-generator with a thermal power of $6.5 \mathrm{kWh} / \mathrm{m}^{3}$ (Barrera, Spanjers, Dewulf, Romero, \& Rosa, 2013; Pazuch et al., 2017). If sugarcane vinasse is converted into bioethanol, from $1 \mathrm{~m}^{3}$ bioethanol, about $115-312 \mathrm{~m}^{3}$ of biogas can be produced, from which $169 \mathrm{~kW}$ of energy can be generated (Meyer et al., 2011).
The total energy in vinasse is about $18 \%$ of the energy produced by bioethanol produced in the plant (Parsaee, Kiani Deh Kiani, \& Karimi, 2019). Sugarcane vinasse wastewater has high organic loading, so anaerobic system would be suited to lower down the concentration of organic, as well as utilized by-product biogas for alternative energy, prior treatment using aerobic system to fulfill stream standard. Thus, for full-scale application and to completely treated sugarcane vinasse wastewater with low cost technology, the combination of anaerobic-aerobic treatment technology could be the best option.

Anaerobic technology is still the main tools for vinasse wastewater treatment. However, there are expected conditions that should be met in order to generate 
maximum biogas production. Nutrients are important due to the low ratio of carbon-to-nitrogen (Moraes, Triolo, Lecona, Zaiat, \& Sommer, 2015). The optimum range is reported as being between 25 and 35 for biogas production (Moraes et al., 2015). To modify carbon-to-nitrogen ratio, addition of materials with high carbon-to nitrogen ratio such as bagasse, straw or filter cake could be done(Moraes et al., 2015). Another preferable co-substrate could be domestic wastewater (Tena, Perez, \& Solera, 2021a, 2021b), wastewater from biodegradable food beverage industries (Boncz, Formagini, Santos, Marques, \& Paulo, 2012) or agriculture waste (Meng et al., 2020; Moraes et al., 2015; Oliveira et al., 2020).

Dilution as a pretreatment is proven to be necessary to lower down the levels of inhibitors, thus it should be maintained. It was shown that vinasse to water ratio of $1: 3$ produced biogas of $37.409 \mathrm{~mL} / \mathrm{g}$ COD (Budiyono \& Sumardiyono, 2013; I Syaichurrozi \& Sumardiono, 2014). Harihastuti, et al (Harihastuti et al., 2021) also proved that theoretical methane yield of diluted vinasse sample (with ratio vinasse to water: 1:4) was higher than undiluted sample. Acidic $\mathrm{pH}$ in vinasse wastewater is not an optimum growth condition for methanogenic bacteria, hence the amount of certain level of alkalinity should be maintained to ensure the buffering capacity in wastewater. To enhance the alkalinity, addition of urea is one of the option. In the anaerobic digestion (AD), urea will be converted into $\mathrm{OH}^{-}$ $+\mathrm{NH}_{4}{ }^{+}$. However, the urea addition could not higher than C:N : 20-40:1 to prevent process failure caused by ammonia inhibition (Boncz et al., 2012). Beside Nitrogen, the addition of phosphate is also important for the stability of anaerobic digestion system, but the phosphate cannot be directly injected to the system. Therefore, urea, $\left(\mathrm{CO}\left(\mathrm{NH}_{2}\right)_{2}\right)$ and sodium phosphate, $\left(\mathrm{NaH}_{2} \mathrm{PO}_{4}\right)$, are added as soluble to optimize nitrogen phosphorus, respectively (Taylor, Siqueira, Damiano, \& Silva, 2013). A study conducted by Boncz, et.al,(Boncz et al., 2012) showed that the optimum urea concentration was $0.215 \mathrm{~g} / \mathrm{g}$ COD for maximum biogas production of $10 \mathrm{~L} / \mathrm{g}$ COD. Review of key parameters for vinasse degradation process is shown in table 3.

Table 3. Review of key parameters to maximize vinasse degradation process

\begin{tabular}{|c|c|c|c|}
\hline Key parameters & Range value & remarks & reference \\
\hline Ratio C/N & $20-40: 1$ & $\begin{array}{l}\text { Above the value can cause ammonia } \\
\text { inhibition that lead to reactor failure }\end{array}$ & (Boncz et al., 2012) \\
\hline Dilution factor & vinasse $:$ water $=3: 1$ & $\begin{array}{l}\text { Could lower down the concentration of } \\
\text { inhibitors, thus enhance methanogenic } \\
\text { activity. } \\
\text { Dilution could also lower down the } \\
\text { concentration of Total Solid to improve the } \\
\text { vinasse biodegradability }\end{array}$ & $\begin{array}{l}\text { (Budiyono \& Sumardiyono, 2013; I } \\
\text { Syaichurrozi \& Sumardiono, 2014) }\end{array}$ \\
\hline $\begin{array}{l}\text { Effluent } \\
\text { recirculation }\end{array}$ & $15 \%$ ratio & $\begin{array}{l}\text { Effluent recirculation could stabilize } \mathrm{pH} \text {. } \\
\text { Recirculation could be applied after initial } \\
\text { addition of alkaline at start up period. }\end{array}$ & $\begin{array}{l}\text { (Fuess, de Araújo Júnior, Garcia, \& Zaiat, } \\
\text { 2017) }\end{array}$ \\
\hline $\mathrm{pH}$ & $\begin{array}{l}\text { Feed stock has to be } \mathrm{pH} 6 \text { at } \\
\text { minimum by adding alkaline with } \\
\text { concentration not more than } 4 \mathrm{~g} / \mathrm{g} \\
\text { COD. }\end{array}$ & $\begin{array}{l}\text { Alkaline such as urea }\left(\mathrm{CO}\left(\mathrm{NH}_{2}\right)_{2} \text {, }\right) \text { and } \\
\text { sodium phosphate }\left(\mathrm{NaH}_{2} \mathrm{PO}_{4}\right) \text { could be } \\
\text { used }\end{array}$ & (Janke et al., 2016) \\
\hline $\begin{array}{l}\text { Co-digested } \\
\text { substrate }\end{array}$ & $\begin{array}{l}\text { Addition of bagasse, straw, filter cake, } \\
\text { cow manure, sludge }\end{array}$ & $\begin{array}{l}\text { Sludge has typical methanogenic activity of } \\
0.25-0.30 \mathrm{mg} \mathrm{CH} 4 / \mathrm{g} \text { VS }\end{array}$ & $\begin{array}{l}\text { (Espańa-gamboa, Mijangos-cortés, } \\
\text { Hernández-zárate, \& Maldonado, 2012; } \\
\text { Gomes, Barros, Maria, Alves, \& Oliveira, } \\
\text { 2016) }\end{array}$ \\
\hline
\end{tabular}




\section{CONCLUSION}

This paper reviews the characteristic, the environmental effect, treatment methods, and the key parameters for maximum biogas production from vinasse. Vinasse has high organic load, thus it is one of the main source of industrial pollution that potentially harmful to the environment. Anerobic digestion is still the most effective treatment method for mitigation, because it can produce biogas as renewable energy. To enhance biogas production, key parameters such as : $\mathrm{C} / \mathrm{N}$ ratio, dilution factor, recirculation, $\mathrm{pH}, \mathrm{HRT}$ and co-digested substrate should be maintained. To reduce cost and to fulfil the stream standard regulation, the combination of several technologies should be applied for wastewater management strategy.

\section{REFERENCES}

Albuquerque, J. N., Ratusznei, S. M., \& Rodrigues, J. A. D. (2019). Biomethane production by thermophilic co-digestion of sugarcane vinasse and whey in an AnSBBR: E ff ects of composition, organic load, feed strategy and temperature. Journal of Environmental Management, 251(September), 109606.

https://doi.org/10.1016/j.jenvman.2019.109606

Barrera, E. L., Spanjers, H., Dewulf, J., Romero, O., \& Rosa, E. (2013). The sulfur chain in biogas production from sulfate-rich liquid substrates: a review on dynamic modeling with vinasse as model substrate, (May), 1405-1420. https://doi.org/10.1002/jctb.4071

Bernal, A. P., Felipe, I., Paula, A., Silva, M., Barros, R. M., \& Ribeiro, E. M. (2017). Vinasse biogas for energy generation in Brazil: An assessment of economic feasibility, energy potential and avoided $\mathrm{CO}_{2}$ emissions. Journal of Cleaner Production. https://doi.org/10.1016/j.jclepro.2017.03.064

Boncz, M. A., Formagini, E. L., Santos, L. S., Marques, R. D., \& Paulo, P. L. (2012). Application of urea dosing for alkalinity supply during anaerobic digestion of vinasse, (around 4), 2453-2460. https://doi.org/10.2166/wst.2012.476
Budiyono, \& Sumardiyono, I. S. (2013). Biogas Production Kinetic from Vinasse Waste in Batch Mode Anaerobic Digestion. World Applied Scinces Journal, 26(11), 1464-1472. https://doi.org/10.5829/idosi.wasj.2013.26.11.14 05

España-gamboa, E. I., Mijangos-cortés, J. O., Hernándezzárate, G., \& Maldonado, J. A. D. (2012). Methane production by treating vinasses from hydrous ethanol using a modified UASB reactor, 1-9.

Ferraz, N., Koyama, M. H., Araújo, M. M. De, \& Zaiat, M. (2016). Thermophilic anaerobic digestion of raw sugarcane vinasse Ant o, 89. https://doi.org/10.1016/j.renene.2015.11.064

Fuess, L. T., de Araújo Júnior, M. M., Garcia, M. L., \& Zaiat, M. (2017). Designing full-scale biodigestion plants for the treatment of vinasse in sugarcane biorefineries: How phase separation and alkalinization impact biogas and electricity production costs? Chemical Engineering Research and Design, 119, 209-220. https://doi.org/10.1016/j.cherd.2017.01.023

Gomes, V., Barros, D., Maria, R., Alves, R., \& Oliveira, D. (2016). Biomethane production from vinasse in upflow anaerobic sludge blanket reactors inoculated with granular sludge. Brazilian Journal of Microbiology, 47(3), 628-639. https://doi.org/10.1016/j.bjm.2016.04.021

Guerreiro, L. F., Rodrigues, C. S. D., Duda, R. M., Oliveira, R. A. De, Boaventura, R. A. R., \& Madeira, L. M. (2016). Treatment of sugarcane vinasse by combination of coagulation / fl occulation and Fenton' s oxidation, 181, 237-248. https://doi.org/10.1016/j.jenvman.2016.06.027

Harihastuti, N., \& Marlena, B. (2018). Bioenergy Potential Based on Vinasse From Ethanol Industrial Waste to Green Energy Sustainability, 02015, 20172019.

Harihastuti, N., Yuliasni, R., Djayanti, S., H, N. I., Rame, R., \& Prasetio, A. (2020). Hybrid Filter Integrated 
technology for generation from vinasse with shorter hydraulic retention time, 10008, 1-9.

Harihastuti, N., Yuliasni, R., Djayanti, S., Handayani, N. I., Rame, R., Prasetio, A., \& Kadier, A. (2021). Full-Scale Application of Up-flow High Rate Anaerobic Reactor with Substrate Modification and Effluent Recirculation for Sugarcane Vinasse Degradation and Biogas Generation, 22(4), 314324.

Janke, L., Leite, A. F., Batista, K., Silva, W., Nikolausz, M., \& Nelles, M. (2016). Bioresource Technology Enhancing biogas production from vinasse in sugarcane biorefineries: Effects of urea and trace elements supplementation on process performance and stability. Bioresource Technology, 1-11. https://doi.org/10.1016/j.biortech.2016.01.110

Janke, L., Leite, A., Nikolausz, M., Schmidt, T., \& Liebetrau, J. (2015). Biogas Production from Sugarcane Waste: Assessment on Kinetic Challenges for Process Designing, 20685-20703. https://doi.org/10.3390/ijms160920685

Jesus, G. C. De, Bastos, R. G., \& Altenhofen, M. (2019). Biocatalysis and Agricultural Biotechnology Production and characterization of alginate beads for growth of immobilized Desmodesmus subspicatus and its potential to remove potassium, carbon and nitrogen from sugarcane vinasse. Biocatalysis and Agricultural Biotechnology, 22 (October), 101438.

https://doi.org/10.1016/j.bcab.2019.101438

Kayhanian, M., \& Rich, D. (1995). Pilot-Scale High Solids Thermophilic Anaerobic Digestion Of Municipal Solid Waste With An Emphasis On Nutrient Requirements. Biomass and Bioenergy, 8 (6).

Lebrero, R., \& Zaiat, M. (2017). Anaerobic Digestion of Sugarcane Vinasse Through a Methanogenic UASB Reactor Followed by a Packed Bed Reactor. https://doi.org/10.1007/s12010-017-2488-2

Marafon, A. C., Salomon, K. R., Amorim, E. L. C., \& Peiter, F. S. (2020). Use of sugarcane vinasse to biogas, bioenergy, and biofertilizer production.
Sugarcane Biorefinery, Technology and Perspectives. Elsevier Inc.

https://doi.org/10.1016/b978-0-12-8142363.00010-x

Marafon, A. C., Salomon, K. R., \& Lucena, E. (2020). Use of sugarcane vinasse to biogas, bioenergy, and biofertilizer production. Sugarcane Biorefinery, Technology and Perspectives. Elsevier Inc. https://doi.org/10.1016/B978-0-12-8142363.00010-X

Meng, L., Jin, K., Yi, R., Chen, M., Peng, J., \& Pan, Y. (2020). Bioresource Technology Enhancement of bioenergy recovery from agricultural wastes through recycling of cellulosic alcoholic fermentation vinasse for anaerobic co- digestion. Bioresource Technology, 311(May), 123511. https://doi.org/10.1016/j.biortech.2020.123511

Meyer, J. H., Rein, P., Turner, P., Administrative, K. M., \& Mcgregor, M. C. (2011). Management Management Manual For The Cane Sugar Manual For The (Final ) Cane Sugar ( Draft).

Moraes, B. S., Triolo, J. M., Lecona, V. P., Zaiat, M., \& Sommer, S. G. (2015). Biogas production within the bioethanol production chain: use of cosubstrates for anaerobic digestion of sugar beet vinasse.

https://doi.org/10.1016/j.biortech.2015.04.089

Naspolini, B. F., Carlos, A., Machado, D. O., Barreiro, W., Junior, C., Maria, D., Cammarota, M. C. (2017). Bioconversion of Sugarcane Vinasse into HighAdded Value Products and Energy. BioMed Research International, 2017, 11.

OECD/FAO. (2019). Chapter 9. Biofuels. In OECD-FAO Agricultural Outlook 2019- 2028 (pp. 205-225). Retrieved from https://doi.org/10.1016/j.jclepro. 2017.03.064

Oliveira, B. G., Mendes, L. W., Smyth, E. M., Tsai, S. M., Feigl, B. J., \& Mackie, R. I. (2020). Assessment of microbial diversity associated with $\mathrm{CH}_{4}$ emission from sugarcane vinasse storage and transportation 
systems. Journal of Environmental Management, 269 (May), 110748.

https://doi.org/10.1016/j.jenvman.2020.110748

Otieno, B., \& Apollo, S. (2020). Journal of Water Process Engineering Energy recovery from biomethanation of vinasse and its potential application in ozonation post-treatment for removal of biorecalcitrant organic compounds. Journal of Water Process Engineering, $\quad$ (July), 101723. https://doi.org/10.1016/j.jwpe.2020.101723

Parsaee, M., Kiani Deh Kiani, M., \& Karimi, K. (2019). A review of biogas production from sugarcane vinasse. Biomass and Bioenergy, 122(January), 117-125.

https://doi.org/10.1016/j.biombioe.2019.01.034

Parsaee, M., Kiani, M., Kiani, D., \& Karimi, K. (2019). Biomass and Bioenergy A review of biogas production from sugarcane vinasse. Biomass and Bioenergy, 122(December 2018), 117-125. https://doi.org/10.1016/j.biombioe.2019.01.034

Pazuch, F. A., Eduardo, C., Nogueira, C., Nelson, S., Souza, M., Micuanski, V. C., ... Lenz, A. M. (2017a). Economic evaluation of the replacement of sugar cane bagasse by vinasse, as a source of energy in a power plant in the state of Paraná , Brazil. Renewable and Sustainable Energy Reviews, 76 (March), 34-42.

https://doi.org/10.1016/j.rser.2017.03.047

Pazuch, F. A., Eduardo, C., Nogueira, C., Nelson, S., Souza, M., Micuanski, V. C. Lenz, A. M. (2017b). Economic evaluation of the replacement of sugar cane bagasse by vinasse, as a source of energy in a power plant in the state of Paraná, Brazil. Renewable and Sustainable Energy Reviews, 76(December 2015), 34-42.

https://doi.org/10.1016/j.rser.2017.03.047

Reis, Cristiano E R, Bento, H. B. S., Alves, T. M., Carvalho, A. K. F., \& Castro, H. F. De. (2019). Vinasse Treatment within the Sugarcane-Ethanol Industry Using Ozone Combined with Anaerobic and
Aerobic

Microbial

Processes.

https://doi.org/10.3390/environments6010005

Reis, Cristiano E Rodrigues, Hu, B., \& Hu, B. (2017). Vinasse from Sugarcane Ethanol Production: Better Treatment or Better Utilization. Frontiers in Energy Research, 5(April), 1-7. https://doi.org/10.3389/fenrg.2017.00007

Santos, F. S., Ricci, B. C., Neta, L. S. F., \& Amaral, M. C. S. (2017). Sugarcane Vinasse Treatment by Twostage Anaerobic Membrane Bioreactor: Department of Sanitary and Environmental Engineering, Universidade Federal de Department of Chemistry , Centro Federal de Educação Tecnológica de Minas Gerais ,. Bioresource Technology.

https://doi.org/10.1016/j.biortech.2017.08.126

Soares, P., Zaiat, M., Augusto, C., \& Tadeu, L. (2019).

Does sugarcane vinasse composition variability affect the bioenergy yield in anaerobic systems? A dual kinetic-energetic assessment. Journal of Cleaner Production, 240, 118005. https://doi.org/10.1016/j.jclepro.2019.118005

Syaichurrozi, I, \& Sumardiono, S. (2014). Effect of Total Solid Content to Biogas Production Rate from Vinasse. International Journal of Engineering, 27(2), 177-184.

https://doi.org/10.5829/idosi.ije.2014.27.02b.02

Syaichurrozi, Iqbal. (2016). Review - Biogas Technology to Treat Bioethanol Vinasse, 4(April), 16-23.

Tadeu, L., Loureiro, M., \& Zaiat, M. (2018). Science of the Total Environment Seasonal characterization of sugarcane vinasse: Assessing environmental impacts from fertirrigation and the bioenergy recovery potential through biodigestion. Science of the Total Environment, 634, 29-40. https://doi.org/10.1016/j.scitotenv.2018.03.326

Tadeu, L., Messias, M., Júnior, D. A., Loureiro, M., \& Zaiat, M. (2017). Chemical Engineering Research and Design Designing full-scale biodigestion plants for the treatment of vinasse in sugarcane biorefineries: How phase separation and 
alkalinization impact biogas and electricity production costs? Chemical Engineering Research and Design, 119, 209-220. https://doi.org/10.1016/j.cherd.2017.01.023

Taylor, P., Siqueira, L. M., Damiano, E. S. G., \& Silva, E. L. (2013). Toxic / Hazardous Substances and Environmental Influence of organic loading rate on the anaerobic treatment of sugarcane vinasse and biogás production in fluidized bed reactor Influence of organic loading rate on the anaerobic treatment of suga. Journal of Environmental Science and Health, 48, 1707-1716. https://doi.org/10.1080/10934529.2013.815535

Tena, M., Perez, M., \& Solera, R. (2021a). Benefits in the valorization of sewage sludge and wine vinasse via a two-stage acidogenic-thermophilic and methanogenic-mesophilic system based on the circular economy concept. Fuel, 296, 120654. https://doi.org/https://doi.org/10.1016/j.fuel.202 1.120654

Tena, M., Perez, M., \& Solera, R. (2021b). Effect of hydraulic retention time on the methanogenic step of a two-stage anaerobic digestion system from sewage sludge and wine vinasse: Microbial and kinetic evaluation. Fuel, 296, 120674. https://doi.org/https://doi.org/10.1016/j.fuel.202 1.120674

Wilkie, A. C., Riedesel, K. J., \& Owens, J. M. (2000). Stillage characterization and anaerobic treatment of ethanol stillage from conventional and cellulosic feedstocks p, 19.

Zimmerman, W. B. (2016). Author's Accepted Manuscript. Chemical Engineering Science. https://doi.org/10.1016/j.ces.2016.09.011 